\title{
Analysis on Ethiopia's Revealed Comparative Advantage and Its Structural Transformation
}

Fetene Bogale Hunegnaw ( $\nabla$ fetene1984@gmail.com )

Adama Science and Technology University

Research

Keywords: Ethiopia's, structural transformation, technology

Posted Date: August 3rd, 2021

DOI: https://doi.org/10.21203/rs.3.rs-715630/v1

License: (c) (i) This work is licensed under a Creative Commons Attribution 4.0 International License. Read Full License 


\section{Abstract}

This study examines Ethiopia's structural transformation by using the revealed comparative advantage approach using export data for years 1996-2018. Primary and low technology manufactured products have comparative advantage over other product groups for the periods 1996 to 2018. However, there is an improvement in all manufactured product categories except except low technology manufactured products (textile, garment and footwear) and resource-based manufactured goods. Thus, based on revealed comparative, structural transformation has occurred in the Ethiopian economy over the last decades but it is very insignificant. Hence, Ethiopia reveals strong comparative advantage in export of primary products, it is important to add value to these products for higher export earnings.

\section{Introduction}

Ethiopia has emerged as one of the fastest-growing economies in Africa in the twenty-first century. Despite this rapid growth, however, structural transformation of the economy remains the country's central challenge (evidence manufacturing sector contribution to GDP is $6.4 \%$ in 2017; manufacturing sector contribution to export $3 \%$ in 2017, African economic outlook country note, 2018). The Government of Ethiopia is striving in taking different actions that are thought to facilitate and enhance the transformation.

Structural transformation refers to "the reallocation of economic activity across three broad sectors (agriculture, manufacturing, and services) that accompanies the process of modern economic growth" (Herrendorf et al., 2013, McMillan, 2014). An economy's structural transformation is important because it reveals the extent of its economic development, and the degree to which policies put in place to steer the economy are effective. Structural change is also a key driver of economic development (McMillan, 2014). Timmer et al. (2012) give a list of four processes that define structural transformation, which are; a decline in the share of agriculture in gross domestic product (GDP) and employment, a rapid urbanization process, a rise in a modern industrial and service sector, and a demographic transition from high births and deaths to low ones. A country's export content can also reflect its structural transformation (Das, 1998). For example, on average for the newly industrializing economies of Hong Kong, Korea, Singapore and Taiwan, from 1975 to 1996, exports of manufactured products as a percentage of total exports increased from approximately $70-90 \%$. Given this connection between the structure of the economy and export content, what can Ethiopia's comparative advantage tell us about the extent to which the structure of the economy has changed and transformed over the years?

Structural transformation of an economy can result from among others, a change in factor endowments and deliberate policies to drive the economy toward a desired path. As an economy grows, its factor endowments will also change, including the skill levels of its people. An improvement in the skill levels of labor can contribute to improving the goods produced in an economy, as the more skilled manpower are applied in productive activities and hence enabling the economy to move from low skilled products to high skilled products. This in turn allows the economy to move from exporting raw materials when the skill levels of its labor were lower, to exporting processed products as the skill levels become higher.

The comparative advantage of a nation can change if a change in government policies invites investment or favors some sectors that were neglected before. Thus, from a policy standpoint, the comparative advantage of a nation can be steered in a direction that policy makers see as encouraging and beneficial to the nation. For example, the governments of the East Asian Tigers put specific policies to steer their economies in a certain way, which accelerated their growth through becoming more export-oriented, resulting in structural changes (Das, 1998). Forbes and Wield (2002) also note that in Korea, subsidies and import protection were combined with export incentives for the local industry, which accelerated the building of an industry that beats world standards. In Singapore, the government combined strong investment in education with pushing industry up the value chain to create a strong industrial sector.

Given that the comparative advantage of a nation can change depending on how an economy's structure evolves over time, the extent and nature of that structural transformation can be deduced from trade data, or specifically, its export content or basket. Indeed, numerous studies have been done which have employed the revealed comparative approach to assess the extent and nature of transformation of various economies. Revealed Comparative Advantage (RCA), developed by Bela Balasssa $(1977,1965)$, builds on the concept of comparative advantage, which reflects a country's specialization, given differences in opportunity costs in producing the goods that it exports. The RCA index has been used in empirical studies on structural transformation, competitiveness and changing specialization. For example, Batra and Khan (2005) undertake a comparative study of China and India's structural transformation using the RCA approach. In terms of sectoral transformation, Saboniene (2011) analyses how Lithuania's manufacturing sector had transformed and how it could be assisted in becoming more competitive in Europe and Beatrice Kalinda Mkend (2012) worked for Tanzania.

This study employs the RCA approach to examine the extent to which the Ethiopia's economy has structurally changed. The results are given and discussed in Sect. 4. The calculated indices are based on the SITC rev.3 products, by technological categories. This paper examines 
whether there has been any shift in Ethiopia's comparative advantage. This assessment is done based on Ethiopia's revealed comparative advantage between 1996-2018.

\section{Data And Methodology}

\subsection{Data}

The data for the calculations were provided by the United Nations Conference on Trade and Development (UNCTAD) Statistical Division. The data are recorded using SITC (rev. 3) industry classification. They are available for the time period 1995-2013. The three digit level of classification provides more detailed information about the commodity structure of exports (255 classes clustered into 10 major groups see Appendix A) and offers an opportunity for more accurate conclusions biased to a lesser extent by excessive aggregation. This paper deals solely with the issue of international trade in goods.

\subsection{Method of Data Analysis}

This Empirical examination of the products in which countries have a comparative advantage in employs the concept of revealed comparative advantage (RCA). It refers to how nations perform relative to each other in terms of trade in specific commodities. Assuming that different nations' trade composition in terms of commodities reflect differences in the relative costs they face in producing them, once calculated, the RCA index "reveals" the comparative advantage of nations. As an economy's structure changes, the RCA can change, as well as if there is an improvement in world demand for the products, and when trade specialization changes (Batra and Khan, 2005).

Balassa's RCA index is calculated as follow

$$
\mathrm{RCA}=\frac{X_{i j} / X_{i}}{X_{w j} / X_{w}}
$$

In Eq. 1, Xij is a country i's exports of commodity j, Xit is country i's total exports, Xwj are world exports of commodity j, and Xw are world total exports. The index thus divides the share of a country's exports of a particular good in its total exports by the world's share of exports of that good in total world exports. The index is used for identifying the commodities in which a particular country's comparative advantage lies or does not lie. The interpretation of the index is straightforward; if the calculated value is greater than 1 in any product category, then it implies that the share of that good in a country's exports is more than the world share, and hence it has a comparative advantage in that particular good. The index is used in identifying the comparative advantage of countries or regions, and it can be calculated for particular markets (for instance the market for minerals or vegetables), regions (for example for the East African Community or the Southern African Development Community) or for the global market. This paper calculates the RCA index for the global market.

\section{Data Analysis And Discussion}

\subsection{Sectorial composition of exports}

Figure 1 in Appendix 1 gives the average percentage export shares of Ethiopia's products by technological categories exports. Primary products export has highest share in total export (17\%). The second highest among technological categories exports is medium technology manufactures: automotive and medium technology manufactures: engineering (15\%). If exports are based on resource endowment, Ethiopia should have highest export of resource based -agro base manufacturing products and low technology manufactures. However, Ethiopia's resource -agro manufacturing export is one of the lowest shares which are only $6 \%$.

\subsection{Inter-temporal variation in Ethiopia's 's RCA and Structural Transformation}

Table 1 results show that Ethiopia had comparative advantage in two product groups in 1996, which is stagnant only in two product groups in 2018. However, there is an improvement in all manufactured product categories except low tech. manufactured products (textile, garment and footwear) and resource-based manufactured goods (in other classifications). Table 2 shows that the number of product groups in which Ethiopia has a comparative advantage does not change from 1996 to 2018. It shows that Ethiopia has comparative advantage only in two product groups. These are primary products group and low tech. manufacturing products such as textile, garment and footwear products among nine listed Rev. 3 SITC classification products. However, RCA for primary products decline from 5.769 in 1996 to 3.22 in 2018 . Its RCA has been declined by $2 \%$ on average from 1996 to 2018 . While low tech. manufactured products( textile, garment and footwear) and resourcebased manufactured goods (agro-based), resource-based manufacturing goods (other classifications), medium technology (manufactured products(engineering), high technology manufacturing goods (other classifications), medium technology manufacturing products (automotive), low technology manufacturing products (other classification), high technology manufacturing products (electronic) and 
medium technology manufacturing products (process) has been grown by $-2 \%, 6 \%, 25 \%, 28 \%, 51 \%, 116 \%, 68 \% 72 \%, 62 \%$ and $56 \%$ from 1996 to 2018. Among all groups of products medium technology manufactured products (engineering) has shown the highest growth rate which is about $116 \%$ on average from 1996 to 2018 . It is evident that the product groups are predominantly primary products. One would have expected that these products groups in which Ethiopia has overall advantage, has losing its advantage over time. It is interesting to note that the numbers of product groups that have shown progress in RCA gained are more than the product groups that their RCA have been declined.

\subsection{Specialization of exports}

Specialization index can indicate a country's position of comparative advantage. Specialization index shows whether a country is net exporter or net importer of particular product. In this regard, specialization index is considered an indicator of comparative advantage. The index ranges between-1 to 1 . Higher value indicates that a country is specialized as exporter, and lower value means that she is specialized as importer. The specialization index shows that Ethiopia is specialized as importer in all technological based manufacturing exports except primary products.

\section{Conclusion}

Ethiopia has emerged as one of the fastest-growing economies in Africa in the twenty-first century. Despite this rapid growth, however, structural transformation of the economy remains the country's central challenge (evidence manufacturing sector contribution to GDP is $6.4 \%$ in 2017; manufacturing sector contribution to export $3 \%$ in 2017. The Government of Ethiopia is striving in taking different actions that are thought to facilitate and enhance the transformation.

This study employs the RCA approach to examine the extent to which the Ethiopia's economy has structurally changed. The calculated indices are based on the SITC rev.3 products, by technological categories. This paper examines whether there has been any shift in Ethiopia's comparative advantage using export data for years 1996-2018.

The RCA approach results show that primary and low technology manufactured products have comparative advantage over other product groups for the periods 1996 to 2018. However, there is an improvement in all manufactured product categories except low technology manufactured products (textile, garment and footwear) and resource-based manufactured goods. Thus, based on revealed comparative advantage, structural transformation has occurred in the Ethiopian economy over the last decades but it is very insignificant. Hence, Ethiopia reveals strong comparative advantage in export of primary products, it is important to add value to these products for higher export earnings.

\section{Declarations}

\section{Availability of data and materials}

The datasets used and/or analysed during the current study are available from the corresponding author on reasonable request

\section{Competing interests}

The author declares that there is no any competing interests.

\section{Funding}

There is no any funding for this research

\section{Authors' contributions}

The corresponding author is a sole author and have worked the whole manuscript

\section{Acknowledgements}

The author thanks United Nation Conference on Development for provision of Data for this study.

\section{Authors' information}

Dr. Fetene Bogale has a PhD in Economics from Seoul National University. Currently he is working as assistant professor of economics in Adama Science and Technology, Adama, Ethiopia.

\section{References}


1. AMADOR, J., S. CABRAL, AND MARIA, J.R., (2009), "What Can We Learn From the Distribution of Trade Patterns? Evidence for Portugal, Spain, Greece and Ireland", Banco de Portugal, Economics and Research Department

2. BALASSA, B., (1965). Trade Liberalization and Revealed Comparative Advantage. The Manchester School of Economic and Social Studies, Vol. 119, 93-123.

3. BALASSA, B., (1977), "Revealed’ Comparative Advantage Revisited: An Analysis of Relative Export Shares of the Industrial Countries,

4. BATRA, A. AND Z. KHAN, (2005), “Revealed Comparative Advantage: An Analysis for India and China”, ICRIER Working Paper No. 168, New Delhi.

5. Beatrice Kalinda Mkend (2012). Tanzania's revealed Comparative Advantage and Structural Transformation. Botswana Journal of Economics

6. BEBEK, U.G., (2011), "Robustness of the Proposed Measures of Revealed Comparative Advantage” School of Economics, University of Kent, Canterbury.

7. BOWEN, P.H., A. HOLLANDER, AND J-M. VIAENE, (2001), Applied International Trade Analysis, The University of Michigan Press.

8. CHENG, T-J., (1993), “Distinctions between The Taiwanese and Korean Approaches to Economic Development”, The Journal of East Asian Affairs, Vol. 7 (1); pp. 116-136.

9. DAS, D.K., (1998), “Changing Comparative Advantage and the Changing Composition of Asian Exports”, Blackwell Publishers Limited, United Kingdom.

10. DEARDORFF, A., (2011), “Comparative Advantage: Theory behind Measurement”, in Globalization, Comparative Advantage and the Changing Dynamics of Trade, OECD Publishing.

11. FORBES, N. AND D. WIELD, (2002), From Followers to Leaders: Managing Technology and Innovation in Newly Industrializing Countries, Routledge, London and New York.

12. HERRENDORF, B., R. ROGERSON AND Á. VALENTINYI, (2013), “Growth and Structural Transformation”, Prepared for the Handbook of Economic Growth.

13. HERRENDORF, B., R. ROGERSON AND Á. VALENTINYI, (2013), “Growth and Structural Transformation”, Prepared for the Handbook of Economic Growth.

14. KOWALSKI, P. and S. F. Stone, (2011) "Breaking through on trade: How a changing world dynamic affects policy", in in Globalization, Comparative Advantage and the Changing Dynamics of Trade, OECD Publishing.

15. MCMILLAN, M., (2014), "The Changing Structure of Africa's Economies”, IFPRI, NBER, Tufts University.

16. PROUDMAN, J. AND S. REDDING, (2000), “Evolving Patterns of International Trade”, Review of International Economics, Vol.8 (3), 373396.

17. RODRIK, D. (2008), “Normalizing Industrial Policy”, The International Bank for Reconstruction and Development/The World Bank, Working Paper No. 3 of the Commission on Growth and Development, Washington.

18. SABONIENĖ, A, (2011), "The transformation of Lithuanian economy: dimension of manufacturing”, Economics and Management, Vol. 16, 295-301.

19. TIMMER, P., M. MCMILLAN, O. BADIANE, D. RODRIK, H. BINSWANGERMKHIZE, AND F. WOUTERSE, (2012), "Patterns of Growth and Structural Transformation in Africa: Trends and Lessons for Future Development Strategies", Thematic Research No. 2, IFPRI.

\section{Tables}


Table 1

RCA index of exports (SITC rev.3 products, by technological categories)

\begin{tabular}{|c|c|c|c|c|c|c|c|c|c|c|}
\hline Year & $\begin{array}{l}\text { Primary } \\
\text { products }\end{array}$ & $\begin{array}{l}\text { Low tech. } \\
\text { man.: textile, } \\
\text { garment and } \\
\text { footwear }\end{array}$ & $\begin{array}{l}\text { Resource- } \\
\text { based } \\
\text { man.: } \\
\text { agro- } \\
\text { based }\end{array}$ & $\begin{array}{l}\text { Resource- } \\
\text { based } \\
\text { man.: } \\
\text { other } \\
\text { class }\end{array}$ & $\begin{array}{l}\text { Medium } \\
\text { tech. man: } \\
\text { engineering }\end{array}$ & $\begin{array}{l}\text { High } \\
\text { tech } \\
\text { man: } \\
\text { other }\end{array}$ & $\begin{array}{l}\text { Medium } \\
\text { tech. man: } \\
\text { automotive }\end{array}$ & $\begin{array}{l}\text { Low } \\
\text { tech. } \\
\text { man: } \\
\text { other } \\
\text { class }\end{array}$ & $\begin{array}{l}\text { High tech } \\
\text { man: } \\
\text { electronic }\end{array}$ & $\begin{array}{l}\text { Medium } \\
\text { tech } \\
\text { man.: } \\
\text { process } \\
\text { c }\end{array}$ \\
\hline 1996 & 5.769 & 1.120 & 0.039 & 0.236 & 0.000 & 0.007 & . & 0.000 & . & 0.000 \\
\hline 1997 & 5.748 & 0.881 & 0.069 & 0.318 & 0.129 & 0.150 & 0.002 & 0.009 & 0.014 & 0.002 \\
\hline 1998 & 6.762 & 0.546 & 0.062 & 0.249 & 0.075 & 0.115 & 0.013 & 0.036 & 0.018 & 0.012 \\
\hline 1999 & 6.647 & 0.615 & 0.112 & 0.207 & 0.165 & 0.161 & 0.016 & 0.027 & 0.020 & 0.010 \\
\hline 2000 & 5.113 & 0.801 & 0.323 & 0.161 & 0.155 & 0.247 & 0.021 & 0.027 & 0.018 & 0.020 \\
\hline 2001 & 6.659 & 1.734 & 0.195 & 0.444 & 0.115 & 0.089 & 0.015 & 0.051 & 0.142 & 0.030 \\
\hline 2002 & 5.267 & 1.323 & 0.714 & 0.123 & 0.013 & 0.044 & 0.009 & 0.013 & 0.012 & 0.010 \\
\hline 2003 & 5.262 & 1.036 & 0.436 & 0.068 & 0.113 & 0.049 & 0.008 & 0.079 & 0.011 & 0.043 \\
\hline 2004 & 4.694 & 0.649 & 0.358 & 0.145 & 0.048 & 0.087 & 0.004 & 0.012 & 0.013 & 0.009 \\
\hline 2005 & 4.945 & 0.892 & 0.569 & 0.179 & 0.070 & 0.034 & 0.004 & 0.019 & 0.008 & 0.015 \\
\hline 2006 & 4.327 & 0.991 & 0.316 & 0.098 & 0.184 & 0.024 & 0.022 & 0.009 & 0.013 & 0.037 \\
\hline 2007 & 4.638 & 1.270 & 0.491 & 0.087 & 0.053 & 0.044 & 0.071 & 0.027 & 0.016 & 0.033 \\
\hline 2008 & 4.186 & 1.177 & 0.384 & 0.041 & 0.057 & 0.241 & 0.107 & 0.125 & 0.026 & 0.058 \\
\hline 2009 & 4.689 & 0.868 & 0.342 & 0.068 & 0.107 & 0.082 & 0.064 & 0.038 & 0.161 & 0.034 \\
\hline 2010 & 4.940 & 1.029 & 0.156 & 0.080 & 0.119 & 0.051 & 0.071 & 0.027 & 0.049 & 0.049 \\
\hline 2011 & 4.464 & 1.702 & 0.196 & 0.124 & 0.059 & 0.052 & 0.063 & 0.027 & 0.017 & 0.036 \\
\hline 2012 & 4.078 & 1.260 & 0.167 & 0.072 & 0.095 & 0.090 & 0.078 & 0.030 & 0.030 & 0.035 \\
\hline 2013 & 3.450 & 1.114 & 0.255 & 0.293 & 0.088 & 0.095 & 0.043 & 0.048 & 0.015 & 0.036 \\
\hline 2014 & 3.273 & 0.888 & 0.184 & 0.658 & 0.049 & 0.071 & 0.045 & 0.029 & 0.034 & 0.028 \\
\hline 2015 & 3.251 & 0.710 & 0.159 & 0.395 & 0.080 & 0.052 & 0.024 & 0.016 & 0.022 & 0.047 \\
\hline 2016 & 3.690 & 1.224 & 0.228 & 0.149 & 0.210 & 0.096 & 0.108 & 0.075 & 0.035 & 0.059 \\
\hline 2017 & 3.617 & 1.019 & 0.209 & 0.373 & 0.133 & 0.104 & 0.084 & 0.045 & 0.032 & 0.067 \\
\hline 2018 & 3.222 & 1.092 & 0.232 & 0.333 & 0.144 & 0.105 & 0.092 & 0.056 & 0.032 & 0.075 \\
\hline Aver & 4.726 & 1.041 & 0.269 & 0.213 & 0.098 & 0.091 & 0.044 & 0.036 & 0.034 & 0.032 \\
\hline
\end{tabular}


Table 2

Growth of RCA index of exports (SITC rev.3 products, by technological categories)

\begin{tabular}{|c|c|c|c|c|c|c|c|c|c|c|}
\hline Year & $\begin{array}{l}\text { Primary } \\
\text { products }\end{array}$ & $\begin{array}{l}\text { Low tech. } \\
\text { man.: textile, } \\
\text { garment and } \\
\text { footwear }\end{array}$ & $\begin{array}{l}\text { Resource- } \\
\text { based } \\
\text { man.: } \\
\text { agro- } \\
\text { based }\end{array}$ & $\begin{array}{l}\text { Resource- } \\
\text { based } \\
\text { man.: } \\
\text { other } \\
\text { class }\end{array}$ & $\begin{array}{l}\text { Medium } \\
\text { tech. man: } \\
\text { engineering }\end{array}$ & $\begin{array}{l}\text { High } \\
\text { tech } \\
\text { man: } \\
\text { other }\end{array}$ & $\begin{array}{l}\text { Medium } \\
\text { tech. man: } \\
\text { automotive }\end{array}$ & $\begin{array}{l}\text { Low } \\
\text { tech. } \\
\text { man: } \\
\text { other } \\
\text { class }\end{array}$ & $\begin{array}{l}\text { High tech } \\
\text { man: } \\
\text { electronic }\end{array}$ & $\begin{array}{l}\text { Medium } \\
\text { tech } \\
\text { man.: } \\
\text { process } \\
\text { c }\end{array}$ \\
\hline \multicolumn{11}{|l|}{1996} \\
\hline 1997 & 0.00 & -0.21 & 0.77 & 0.35 & . & 20.43 & . & . & . & . \\
\hline 1998 & 0.18 & -0.38 & -0.10 & -0.22 & -0.42 & -0.23 & 5.50 & 3.00 & 0.29 & 5.00 \\
\hline 1999 & -0.02 & 0.13 & 0.81 & -0.17 & 1.20 & 0.40 & 0.23 & -0.25 & 0.11 & -0.17 \\
\hline 2000 & -0.23 & 0.30 & 1.88 & -0.22 & -0.06 & 0.53 & 0.31 & 0.00 & -0.10 & 1.00 \\
\hline 2001 & 0.30 & 1.16 & -0.40 & 1.76 & -0.26 & -0.64 & -0.29 & 0.89 & 6.89 & 0.50 \\
\hline 2002 & -0.21 & -0.24 & 2.66 & -0.72 & -0.89 & -0.51 & -0.40 & -0.75 & -0.92 & -0.67 \\
\hline 2003 & 0.00 & -0.22 & -0.39 & -0.45 & 7.69 & 0.11 & -0.11 & 5.08 & -0.08 & 3.30 \\
\hline 2004 & -0.11 & -0.37 & -0.18 & 1.13 & -0.58 & 0.78 & -0.50 & -0.85 & 0.18 & -0.79 \\
\hline 2005 & 0.05 & 0.37 & 0.59 & 0.23 & 0.46 & -0.61 & 0.00 & 0.58 & -0.38 & 0.67 \\
\hline 2006 & -0.12 & 0.11 & -0.44 & -0.45 & 1.63 & -0.29 & 4.50 & -0.53 & 0.63 & 1.47 \\
\hline 2007 & 0.07 & 0.28 & 0.55 & -0.11 & -0.71 & 0.83 & 2.23 & 2.00 & 0.23 & -0.11 \\
\hline 2008 & -0.10 & -0.07 & -0.22 & -0.53 & 0.08 & 4.48 & 0.51 & 3.63 & 0.63 & 0.76 \\
\hline 2009 & 0.12 & -0.26 & -0.11 & 0.66 & 0.88 & -0.66 & -0.40 & -0.70 & 5.19 & -0.41 \\
\hline 2010 & 0.05 & 0.19 & -0.54 & 0.18 & 0.11 & -0.38 & 0.11 & -0.29 & -0.70 & 0.44 \\
\hline 2011 & -0.10 & 0.65 & 0.26 & 0.55 & -0.50 & 0.02 & -0.11 & 0.00 & -0.65 & -0.27 \\
\hline 2012 & -0.09 & -0.26 & -0.15 & -0.42 & 0.61 & 0.73 & 0.24 & 0.11 & 0.76 & -0.03 \\
\hline 2013 & -0.15 & -0.12 & 0.53 & 3.07 & -0.07 & 0.06 & -0.45 & 0.60 & -0.50 & 0.03 \\
\hline 2014 & -0.05 & -0.20 & -0.28 & 1.25 & -0.44 & -0.25 & 0.05 & -0.40 & 1.27 & -0.22 \\
\hline 2015 & -0.01 & -0.20 & -0.14 & -0.40 & 0.63 & -0.27 & -0.47 & -0.45 & -0.35 & 0.68 \\
\hline 2016 & 0.14 & 0.72 & 0.43 & -0.62 & 1.63 & 0.85 & 3.50 & 3.69 & 0.59 & 0.26 \\
\hline 2017 & -0.02 & -0.17 & -0.08 & 1.50 & -0.37 & 0.08 & -0.22 & -0.40 & -0.09 & 0.14 \\
\hline 2018 & -0.11 & 0.07 & 0.11 & -0.11 & 0.08 & 0.01 & 0.10 & 0.24 & 0.00 & 0.12 \\
\hline Aver & -0.02 & 0.06 & 0.25 & 0.28 & 0.51 & 1.16 & 0.68 & 0.72 & 0.62 & 0.56 \\
\hline
\end{tabular}


Table 3

Specialization index of exports based on SITC rev.3 products, by technological categories

\begin{tabular}{|c|c|c|c|c|c|c|c|c|c|c|}
\hline YEAR & $\begin{array}{l}\text { Primary } \\
\text { products }\end{array}$ & $\begin{array}{l}\text { Resource- } \\
\text { based } \\
\text { manu: } \\
\text { agro- } \\
\text { based }\end{array}$ & $\begin{array}{l}\text { Resoubased } \\
\text { man: other }\end{array}$ & $\begin{array}{l}\text { Low } \\
\text { techn.manuf: } \\
\text { textile, } \\
\text { garment and } \\
\text { footwear }\end{array}$ & $\begin{array}{l}\text { Low } \\
\text { tech. } \\
\text { manu: } \\
\text { other } \\
\text { produ }\end{array}$ & $\begin{array}{l}\text { Medium } \\
\text { tech manu: } \\
\text { automotive }\end{array}$ & $\begin{array}{l}\text { Medium } \\
\text { tech } \\
\text { manu: } \\
\text { process }\end{array}$ & $\begin{array}{l}\text { Medium } \\
\text { tech man: } \\
\text { engineering }\end{array}$ & $\begin{array}{l}\text { High tech } \\
\text { mau: } \\
\text { electronic } \\
\text { and } \\
\text { electrical }\end{array}$ & $\begin{array}{l}\text { High } \\
\text { tech } \\
\text { manu: } \\
\text { other }\end{array}$ \\
\hline 1995 & 0.352 & -0.936 & -0.731 & -0.088 & -0.988 & -0.997 & -0.988 & -0.842 & -0.984 & -0.869 \\
\hline 1996 & 0.805 & -0.976 & -0.914 & -0.285 & -1.000 & . & -1.000 & -1.000 & . & -0.997 \\
\hline 1997 & 0.815 & -0.932 & -0.802 & -0.129 & -0.993 & -0.998 & -0.999 & -0.903 & -0.973 & -0.898 \\
\hline 1998 & 0.607 & -0.946 & -0.904 & -0.443 & -0.976 & -0.987 & -0.993 & -0.944 & -0.974 & -0.905 \\
\hline 1999 & 0.575 & -0.923 & -0.911 & -0.438 & -0.984 & -0.992 & -0.996 & -0.907 & -0.972 & -0.912 \\
\hline 2000 & 0.573 & -0.833 & -0.936 & -0.305 & -0.981 & -0.984 & -0.989 & -0.874 & -0.959 & -0.801 \\
\hline 2001 & 0.357 & -0.955 & -0.909 & -0.289 & -0.985 & -0.994 & -0.993 & -0.951 & -0.866 & -0.957 \\
\hline 2002 & 0.563 & -0.670 & -0.949 & -0.315 & -0.993 & -0.995 & -0.996 & -0.992 & -0.984 & -0.982 \\
\hline 2003 & 0.032 & -0.881 & -0.979 & -0.500 & -0.971 & -0.996 & -0.985 & -0.948 & -0.992 & -0.986 \\
\hline 2004 & 0.297 & -0.874 & -0.947 & -0.649 & -0.994 & -0.998 & -0.998 & -0.977 & -0.991 & -0.956 \\
\hline 2005 & 0.443 & -0.786 & -0.936 & -0.567 & -0.993 & -0.998 & -0.995 & -0.975 & -0.993 & -0.985 \\
\hline 2006 & 0.406 & -0.898 & -0.974 & -0.618 & -0.996 & -0.995 & -0.989 & -0.940 & -0.987 & -0.988 \\
\hline 2007 & 0.537 & -0.835 & -0.973 & -0.492 & -0.992 & -0.976 & -0.989 & -0.984 & -0.990 & -0.983 \\
\hline 2008 & 0.117 & -0.903 & -0.991 & -0.421 & -0.963 & -0.953 & -0.986 & -0.981 & -0.991 & -0.894 \\
\hline 2009 & 0.416 & -0.900 & -0.983 & -0.471 & -0.990 & -0.974 & -0.992 & -0.967 & -0.936 & -0.966 \\
\hline 2010 & 0.495 & -0.938 & -0.970 & -0.440 & -0.988 & -0.971 & -0.981 & -0.947 & -0.972 & -0.974 \\
\hline 2011 & 0.454 & -0.935 & -0.950 & -0.159 & -0.988 & -0.972 & -0.986 & -0.973 & -0.983 & -0.972 \\
\hline 2012 & 0.607 & -0.939 & -0.978 & -0.326 & -0.990 & -0.969 & -0.988 & -0.964 & -0.976 & -0.951 \\
\hline 2013 & 0.514 & -0.902 & -0.871 & -0.342 & -0.980 & -0.980 & -0.985 & -0.963 & -0.984 & -0.955 \\
\hline 2014 & 0.535 & -0.919 & -0.786 & -0.527 & -0.990 & -0.977 & -0.989 & -0.977 & -0.976 & -0.954 \\
\hline 2015 & 0.397 & -0.930 & -0.851 & -0.649 & -0.994 & -0.988 & -0.984 & -0.961 & -0.985 & -0.965 \\
\hline 2016 & 0.446 & -0.923 & -0.951 & -0.536 & -0.978 & -0.943 & -0.982 & -0.923 & -0.971 & -0.965 \\
\hline 2017 & 0.401 & -0.915 & -0.864 & -0.547 & -0.985 & -0.956 & -0.978 & -0.945 & -0.976 & -0.952 \\
\hline 2018 & 0.344 & -0.909 & -0.877 & -0.532 & -0.982 & -0.953 & -0.976 & -0.943 & -0.975 & -0.954 \\
\hline Aver & 0.462 & -0.898 & -0.914 & -0.420 & -0.986 & -0.980 & -0.989 & -0.949 & -0.974 & -0.947 \\
\hline
\end{tabular}

Figures 


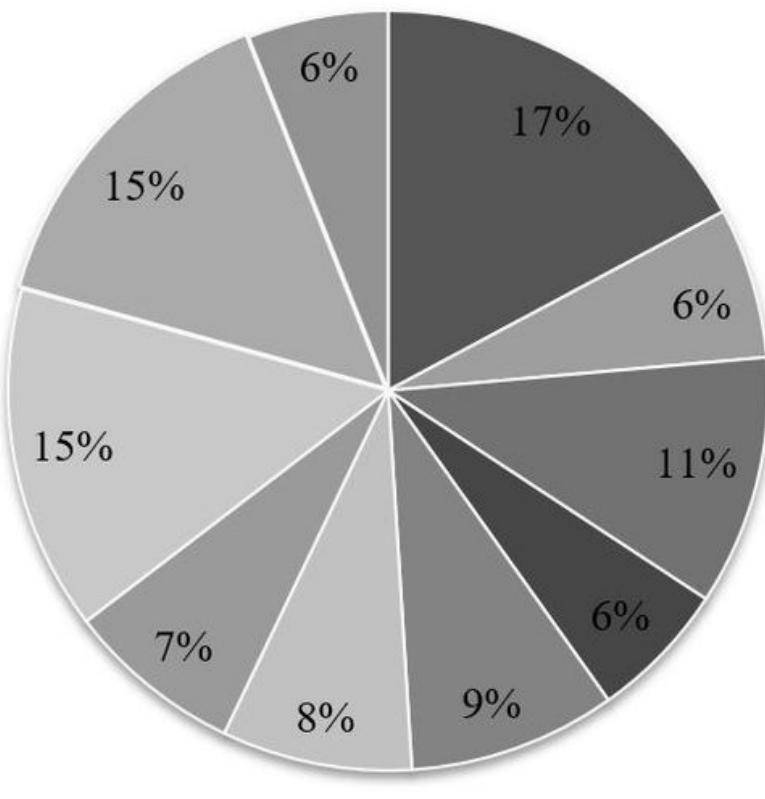

- Primary products (Lall classification)

- Resource-based manufactures: agro-based (Lall classification)

- Resource-based manufactures: other (Lall classification)

- Low technology manufactures: textile, garment and footwear (Lall classification)

- Low technology manufactures: other products (Lall classification)

- Medium technology manufactures: automotive (Lall classification)

- Medium technology manufactures: process (Lall classification)

* Medium technology manufactures: engineering (Lall classification)

- High technology manufactures: electronic and electrical (Lall classification)

- High technology manufactures: other (Lall classification)

Figure 1

SITC rev. products by technological categories

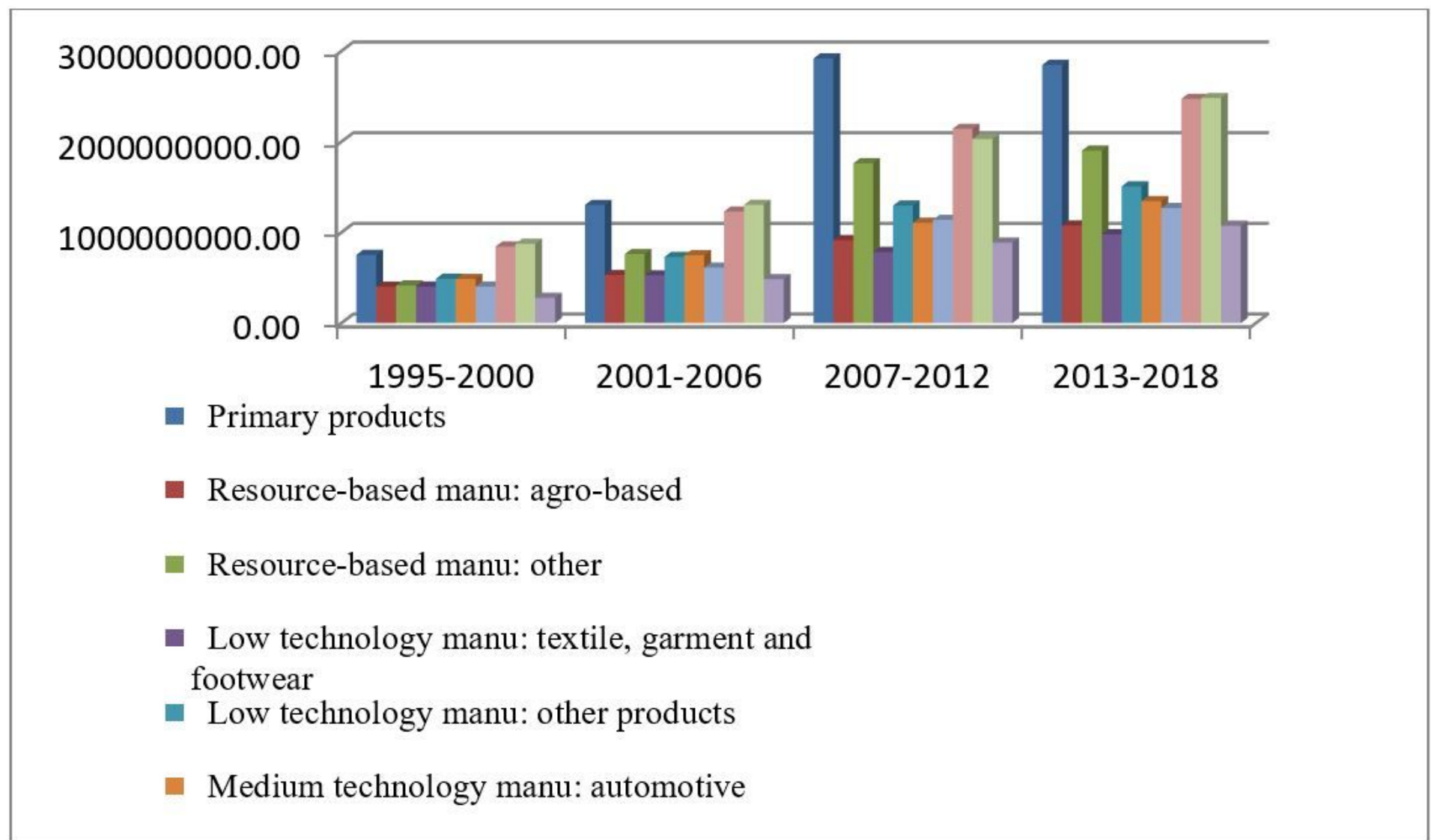

Figure 2

SITC rev.3 products, by technological categories 